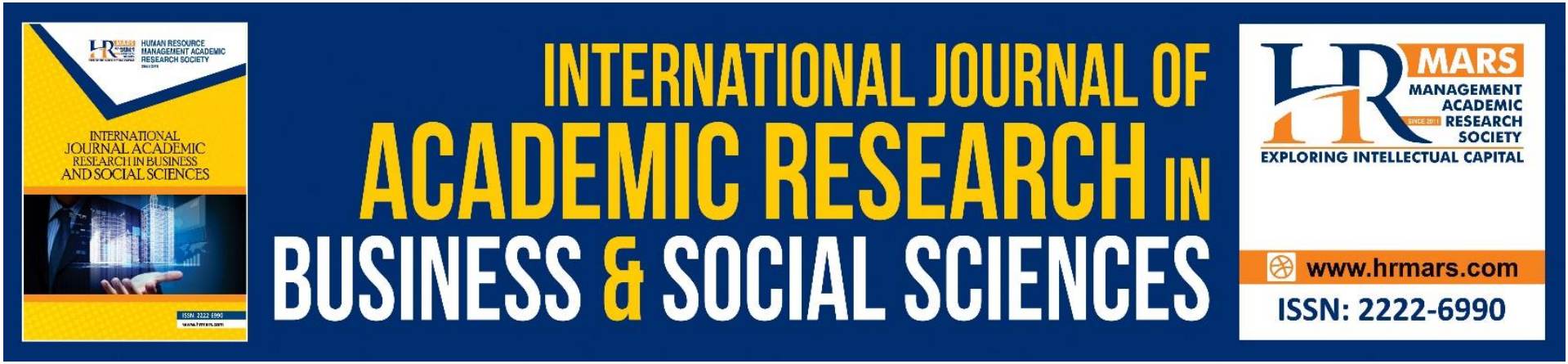

\title{
Physical Inactivity among University Students
}

Annurizal Anuar, Nor Zaihan Mat Hasan @ Hussin, Siti Noorsuriani Maon, Naffisah Mohd Hassan, Mohd Zulkifli Abdullah, Idaya Husna Mohd \& Zahariah Sahudin

To Link this Article: http://dx.doi.org/10.6007/IJARBSS/v11-i5/9934

DOI:10.6007/IJARBSS/v11-i5/9934

Received: 05 April 2021, Revised: 30 April 2021, Accepted: 05 May 2021

Published Online: 17 May 2021

In-Text Citation: (Anuar et al., 2021)

To Cite this Article: Anuar, A., Hussin, N. Z. M. H. @, Maon, S. N., Hassan, N. M., Abdullah, M. Z., Mohd, I. H., \& Sahudin, Z. (2021). Physical Inactivity among University Students. International Journal of Academic Research in Business and Social Sciences, 11(5), 356-366.

Copyright: @ 2021 The Author(s)

Published by Human Resource Management Academic Research Society (www.hrmars.com)

This article is published under the Creative Commons Attribution (CC BY 4.0) license. Anyone may reproduce, distribute, translate and create derivative works of this article (for both commercial and non-commercial purposes), subject to full attribution to the original publication and authors. The full terms of this license may be seen at: http://creativecommons.org/licences/by/4.0/legalcode

Vol. 11, No. 5, 2021, Pg. 356 - 366

http://hrmars.com/index.php/pages/detail/IJARBSS

Full Terms \& Conditions of access and use can be found at http://hrmars.com/index.php/pages/detail/publication-ethics 


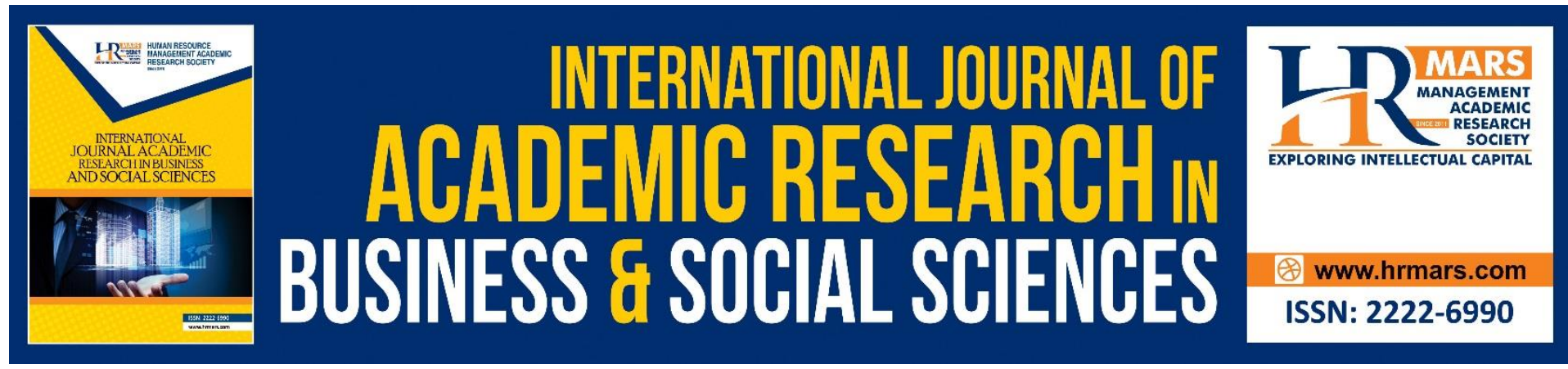

\title{
Physical Inactivity among University Students
}

\author{
Annurizal Anuar, Nor Zaihan Mat Hasan @ Hussin, Siti \\ Noorsuriani Maon, Naffisah Mohd Hassan, Mohd Zulkifli \\ Abdullah, Idaya Husna Mohd \& Zahariah Sahudin
}

Faculty of Business and Management, Universiti Teknologi MARA (UiTM) Selangor, Email: annurizal@uitm.edu.my,norzaihanmh@uitm.edu.my, sitinoor123@uitm.edu.my, naffi885@uitm.edu.my,m_zulkifli@uitm.edu.my, idayahusna@uitm.edu.my, zahariah128@uitm.edu.my

\section{Abstract}

Physical activity is essential for health protection and disease prevention. However, university students are more willing to spend more time studying than participating. Research has shown in recent years that barriers lead to the lack of young adults' involvement in physical activity. This paper mainly aims to investigate differences in attributes towards the engagement of students in physical activity. A cross-sectional survey of undergraduate students was carried out at selected faculties. A self-administered questionnaire was constructed from established questionnaire. There were 28 elements to be evaluated at this point under internal and external attributes. A questionnaire was created, asking respondents to rate on a 5-point scale the attributes that affect physical activities. A total of 361 respondents was valid for data analysis with $72.6 \%$ females and $27.4 \%$ (99) males. Comparison analysis was then used to examine the differences in mean scores between active and less respondents. Both external and internal barriers in physical activity were found statistically significant difference in mean scores. External barriers in physical activity were higher values of mean score compared to internal barriers. Lack of time due to social and family responsibilities was considered as most important barriers in physical activity. Future research at large scale and targeting other population are needed to help nation achieved SDGs 2030 concerning improving healthy lifestyle and promote well-being for all at all ages. Keywords: Physical Activity, University Students, Internal Barriers and External Barriers.

\section{Introduction}

Physical activity is crucial to the improvement and maintenance of the health and wellbeing of all people. Regular participation in moderate to intense physical exercise will greatly reduce the cause of cardiovascular disease and the risk of death (Rogers et al., 2018). Approximately one-third of the world's population does not appear involved in physical activity, which may increase health and economic issues. Several services are available to encourage physical activities in primary, secondary and tertiary institutions and it has become part of the curriculum in both schools and universities. Unfortunately, research shows that the participation rate of young adults has steadily declined (Kann et al., 2018; Trost et al., 2002). Sandu et al., (2018) stated that, the lack of young physical exercise might increase the 
risk of cardiovascular disease, cancer, and osteoporosis in later life, and increase the obesity of people who are less active in physical exercise.

The 2019 National Health and Morbidity Survey (NHMS) reported that 1 in 4 of Malaysian adults aged 16 and over did not exercise, and $39 \%$ of them were students (Institute for Public Health (IPH), 2019). The 2014 Malaysian Adult Nutrition Survey (MANS) showed that $36.9 \%$ of Malaysians between the ages of 18 and 59 are physically inactive (Aris et al, 2014). Most of the population (74\% of the day) spends time on sedentary habits, such as sleeping or lying down (Poh et al., 2010). These figures show that a major public health issue in Malaysia is physical inactivity among adults. Therefore, it is important to understand the factors that affect physical inactivity, especially in the local environment, to solve this problem. This study is therefore aimed at examining the differences in attributes toward physical activity participation among university students.

\section{Literature Review}

Physical activity (PA) has been recognised to help people, increase cognitive ability, and enhance the overall quality of life (Powell \& Pratt, 1996). A study by Zwolinsky et. al in 2016 found that it is essential to promote, introduce and implement adult healthy lifestyle program and physical sports activity to target inactive audiences among them in addition, being physically active not only increases physical fitness but also improves mental health (Fuchs, 2015; Sullum et al., 2000; Weyerer \& Kupfer, 1994) and decreases signs of depression and anxiety (Paluska \& Schwenk, 2011). Moreover, it has been shown that PA decreases the risk of cardiovascular diseases and other chronic diseases, including diabetes mellitus, hypertension, obesity, colon and breast cancer and osteoporosis (Warburton et al., 2006)

A recent national survey conducted in Malaysia in 2019 found that 1 in 4 of Malaysian adults aged 16 and over did not exercise, and 39\% of them were students (Institute for Public Health (IPH), 2019). In addition, $28 \%$ of women, 59\% Malaysian with a minimum age of 75 and over, and $27 \%$ of urban residents have the least physical activity. Although the number of percentages has fallen from $35.7 \%$ and $33.5 \%$ in 2011 and 2015 to $25.1 \%$ in 2019, these statistics show that adult inactivity is a major public health problem in Malaysia.

Studies have indicated that internal and external barriers could be attributed to an awareness of the importance of the physical activity. External barrier is defined as beyond the control of an individual, whereas internal barriers are factors determined by the personal decision of an individual (Daskapan et al., 2006; Gómez-López et al., 2010; Herazo-Beltrán et al., 2017; Korkiangas et al., 2009).

An example of internal barriers is from a study by Saleem et al. (2018) which showed that students involved in several activities at the schools, reported of lack of energy where they were feeling tired and exhausted as a significant cause of physical inactivity. Due to a busy schedule, they become short of energy and want to rest instead of doing physical activity. They were too stressed and tired to get involved with physical activity after school hours.

An external barrier to physical activity is social support. It has previously been established as important factors to assess students' levels of physical activity (Allison et al., 1999, Leslie et al., 1999, Wallace et al., 2000, Bray, 2007). Young adults who receive social support to participate in physical activities may also feel valuable and motivated to participate in these activities and the family environment (mother, father and siblings) and peers also have a substantial impact on participation in physical activity (Eskiler and Küçükibiş, 2019). 


\section{Methodology}

The sampling frame for this research are students from UiTM Puncak Alam and the number of respondents that are selected is based on the Krejcie and Morgan Table (Morgan, 1971) where the population were $1,000,000$ resulted 384 sample needed for this study. A snowball sampling technique was employed in this present research. Data has been obtained through a self-administrated structured survey question online. The researcher used an established questionnaire from Endozo \& Oluyinka (2019) were used in this study. At this stage, there were 28 items under internal and external attributes to be examined. A questionnaire was produced, asking respondents to rate the attributes that affect physical activities on a 5-point scale with anchors of $1=$ Strongly disagree to $5=$ Strongly agree. The three components of internal factors are lack of energy, lack of motivation and lack of selfconfidence. The other three components are the external factors: including lack of resources, lack of social support and lack of time. Data was then collected, and a total of 384 responses were managed to be obtained and only 361 were valid for data analysis purposes.

\section{Data Analysis}

Descriptive statistic was used to study the obtained data using IBM SPSS version 26. Frequencies, mean, and standard deviation were used to describe the demographic background of respondents. To ensure goodness of measures, convergent validity and reliability for the instrument were applied. Both descriptive and inferential statistics were applied using statistical package for social science software (IBM SPSS version 26.0). Simple frequencies were used to study the characteristics of respondents. Comparison analysis was conducted to assess active and non-active students, particularly in internal and external attributes that affect physical activities.

\section{Findings}

\section{Description of the respondents}

Table 1 shows the demographic characteristics of the respondents. Of total 361 respondents took part in this study; half of them (49.9\%) participated actively in physical activity and the other half $(50.1 \%)$ did not participate in physical activity. Overall, majority of the respondents were female (72.6\%), not married $(93.9 \%)$ and more than half of the respondents were at range between $22-24$ years old. There were $38.5 \%$ from lower-level semester; including Semester 1, Semester 2, and Semester 3; and more than half $(61.5 \%)$ were upper-level semester, i.e., Semester 4 onwards. Male students were found more active than female students. Students from range age between 22 to 24 years were reported had participated actively in regular physical activity and students were single more active. Students from lower-level semester were reported not active in physical activity, however students from upper-level semester were had active participation. 
Table 1 Demographic profile

\begin{tabular}{llllllll}
\hline No & Variable & & Total $(\mathrm{n}=361)$ & \multicolumn{2}{l}{$\begin{array}{l}\text { Active } \\
(\mathrm{n}=180 ; 49.9 \%)\end{array}$} & \multicolumn{2}{l}{$\begin{array}{l}\text { Non-Active } \\
(\mathrm{n}=181 ; 50.1 \%)\end{array}$} \\
\hline 1 & Gender & Male & $99(27.4)$ & 53 & $29.4 \%$ & 46 & 25.4 \\
& & Female & $262(72.6)$ & 127 & $70.6 \%$ & 135 & 74.6 \\
\hline 2 & Age & $19-21$ & $74(20.4)$ & 33 & $18.3 \%$ & 41 & $22.7 \%$ \\
& & $22-24$ & $222(61.5)$ & 121 & $67.2 \%$ & 101 & $55.8 \%$ \\
& $>25$ & $65(18)$ & 26 & $14.4 \%$ & 39 & $21.5 \%$ \\
\hline 3 & Semester & 1 & $74(20.5)$ & 33 & $18.3 \%$ & 41 & $22.7 \%$ \\
& & 2 & $42(11.6)$ & 26 & $14.4 \%$ & 16 & $8.8 \%$ \\
& 3 & $23(6.4)$ & 8 & $4.4 \%$ & 15 & $8.3 \%$ \\
& 4 & $35(9.7)$ & 11 & $6.1 \%$ & 24 & $13.3 \%$ \\
& & 5 & $51(14.1)$ & 30 & $16.7 \%$ & 21 & $11.6 \%$ \\
& 6 & $136(37.7)$ & 72 & $40 \%$ & 64 & 35.3 \\
\hline
\end{tabular}

Data results reported that out of 262 female respondents; nearly half of them (49.9\%) participated actively in physical activity and the other half students $(50.1 \%)$ did not participate in physical activity.

Details of the survey's findings are shown in Table 2. Nearly $70 \%$ students, who actively participated in physical activity, had a disagree level of agreement that the exercise was unpleasant and too tiring activities ( $n=125 ; 69.5 \%)$. However, students; either actively or less participated in physical activity strongly disagreed and disagreed that they had no energy as much as they could exercise; then thought of other recreational activities with friends was even more entertaining than exercise; did not consider exercise to have a have a positive effect on their health; were concerned about their appearance when exercising; and did not think about their ability to exercise. 
Table 2 Frequency of Attributes towards to Physical Activity Involvement ( $N=361)$

\begin{tabular}{|c|c|c|c|c|c|c|c|}
\hline \multirow{2}{*}{\multicolumn{2}{|c|}{ ITEMS }} & \multicolumn{2}{|l|}{ ALL } & \multicolumn{2}{|c|}{ Active $(n=181)$} & \multicolumn{2}{|c|}{$\begin{array}{l}\text { Less } \\
(\mathrm{n}=180)\end{array}$} \\
\hline & & \multirow{2}{*}{$\begin{array}{l}M \\
2.166\end{array}$} & \multirow{2}{*}{$\begin{array}{l}\text { SD } \\
\mathbf{0 . 6 4 7}\end{array}$} & \multirow{2}{*}{$\begin{array}{l}M \\
2.007\end{array}$} & \multirow{2}{*}{$\begin{array}{l}\text { SD } \\
0.618\end{array}$} & \multirow{2}{*}{$\begin{array}{l}M \\
2.323\end{array}$} & \multirow{2}{*}{$\begin{array}{l}\text { SD } \\
0.638\end{array}$} \\
\hline INT & RNAL BARRIERS & & & & & & \\
\hline Q1 & $\begin{array}{l}\text { I have been thinking about exercising is } \\
\text { difficult and too tiring. }\end{array}$ & 2.387 & 0.869 & 2.164 & 0.744 & 2.608 & 0.928 \\
\hline \multirow[t]{2}{*}{ Q2 } & $\begin{array}{l}\text { I have no energy as much as to be able to do } \\
\text { exercise }\end{array}$ & 2.163 & 0.815 & 2.011 & 0.762 & 2.315 & 0.8401 \\
\hline & Sum of Perceived of Lack of Energy & & & & & & 551 \\
\hline Q3 & $\begin{array}{l}\text { I have been thinking about other } \\
\text { recreational activities with my friends are } \\
\text { more entertaining than exercise. }\end{array}$ & & 9 & 2 & & & 01 \\
\hline \multirow[t]{2}{*}{ Q4 } & $\begin{array}{l}\text { I have not been thinking about exercise has } \\
\text { positive effects on my health. }\end{array}$ & 1.831 & 0.902 & 1.661 & 0.813 & 2.000 & 0.954 \\
\hline & ed of Lack of Motivation & 989 & 24 & & & 315 & 412 \\
\hline Q5 & een worried about my looks when I & 2.296 & 1.058 & 2.183 & 0.936 & 2.409 & 1.159 \\
\hline \multirow[t]{2}{*}{ Q6 } & $\begin{array}{l}\text { I have not been thinking about my ability to } \\
\text { exercise. }\end{array}$ & 2.158 & 0.986 & 2.022 & 0.915 & 2.293 & 1.037 \\
\hline & Sum of Perceived of Lack of Self-confidence & 4.454 & 1.732 & 4.206 & 1.609 & 4.702 & 1.816 \\
\hline \multicolumn{2}{|c|}{ EXTERNAL BARRIERS } & 2.41 & 0.771 & 2.123 & 0.752 & 2.696 & 0.678 \\
\hline Q7 & There is no fitness & 2.692 & 1.148 & 2.472 & 1.08 & 2.912 & 1.175 \\
\hline \multirow[t]{2}{*}{ Q8 } & $\begin{array}{l}\text { I have no exercise equipment at home that I } \\
\text { can use. }\end{array}$ & 2.629 & 1.216 & 2.317 & 2.203 & 2.939 & 1.151 \\
\hline & Sum of Perceived of Lack of Resources & 321 & 107 & .789 & & 851 & 2.032 \\
\hline Q9 & $\begin{array}{l}\text { My family or friends do not encourage me to } \\
\text { exercise. }\end{array}$ & 1.873 & 0.928 & 1.683 & 0.7801 & 2.061 & 1.023 \\
\hline \multirow[t]{2}{*}{ Q10 } & $\begin{array}{l}\text { My parents give academic success priority } \\
\text { over exercise. }\end{array}$ & 2.138 & 1.042 & 2.05 & 1.11 & 2.226 & 0.965 \\
\hline & Sum of Perceived of Lack of Support & 4.011 & 1.81 & 3.733 & כבט. & .287 & 1.919 \\
\hline Q11 & $\begin{array}{l}\text { I have no leisure time for exercise because } \\
\text { of my busy lesson schedule. }\end{array}$ & 2.546 & 1.127 & 2.133 & 1.005 & 2.956 & 1.094 \\
\hline \multirow[t]{2}{*}{ Q12 } & $\begin{array}{l}\text { I have no leisure time for exercise because } \\
\text { of my social and family responsibilities. }\end{array}$ & 2.585 & 1.113 & 2.083 & 1.04 & 3.083 & 0.948 \\
\hline & Sum of Perceived of Lack of Time & 5.13 & 2.109 & 4.217 & 1.873 & 6.039 & 1.933 \\
\hline
\end{tabular}

Notes: $M=$ Mean; $S D=$ Standard Deviation

Table 2 describes perceived barriers to physical activity of the respondents. Differences in mean scores of perceived barriers between active respondents and less active respondents was conducted. Less active respondents have higher mean scores in perceived barriers of physical activity towards all dimensions of both internal and external barriers. The total mean score of external barriers was reported to be higher than the mean score of the internal barriers ( $M=2.696$, SD 0.678; $M=2.323$ ).

Data findings revealed that lack of time was the highest mean value among less active respondents ( $M=6.039$; $S D=1.933)$; however, lack of resources was the highest mean value 
among active respondents $(M=4.789 ; S D=2.052)$. It was reported that less active respondents did not have time for physical activity due to their social and family responsibilities $(M=3.083$; $\mathrm{SD}=0.948$ ). Referring to the internal barriers, lack of energy was the highest mean value among less active respondents $(M=4.923 ; S D=1.551)$; though, lack of self-confidence was the highest mean value among active respondents $(M=4.206 ; S D=1.609)$. It was reported that less active respondents believed the exercise was a difficult and tiring activity $(M=2.603$; $\mathrm{SD}=0.928)$.

Table 3 shows the differences in attributes, including internal and external attributes, between respondents who had active participation in physical activity and less active participation in physical activity. An independent-samples t-test was conducted to compare both external and internal attributes between the two groups of respondents: active participation and less active participation in physical activity.

Table 3 Differences between Active and Less active Students

\begin{tabular}{|c|c|c|c|c|c|c|c|c|c|c|c|}
\hline $\begin{array}{l}\text { Variabl } \\
\text { e }\end{array}$ & $\begin{array}{l}\text { Typ } \\
\text { e }\end{array}$ & $\mathrm{M}$ & SD & Df & $\mathrm{t}$ & $p$ & $\begin{array}{l}\text { M } \\
\text { Differen } \\
\text { ce }\end{array}$ & $\begin{array}{l}\text { SE } \\
\text { Differen } \\
\text { ce }\end{array}$ & \multicolumn{2}{|c|}{$95 \% \mathrm{Cl}$} & $\begin{array}{l}\text { Cohen' } \\
\text { S D }\end{array}$ \\
\hline \multirow{6}{*}{$\begin{array}{l}\text { Interna } \\
\text { I } \\
\text { barrier } \\
\mathrm{s}\end{array}$} & \multirow{5}{*}{1} & & & \multirow{6}{*}{$\begin{array}{l}35 \\
9\end{array}$} & \multirow{6}{*}{-4.786} & \multirow{6}{*}{$\begin{array}{l}.00 \\
0\end{array}$} & \multirow{6}{*}{-.317} & \multirow{6}{*}{0.066} & UL & $\mathrm{LL}$ & \multirow{6}{*}{0.580} \\
\hline & & & & & & & & & \multirow{5}{*}{$\begin{array}{l}- \\
.447\end{array}$} & \multirow{5}{*}{$\begin{array}{l}- \\
.18 \\
6\end{array}$} & \\
\hline & & 2.0 & .61 & & & & & & & & \\
\hline & & 06 & 9 & & & & & & & & \\
\hline & & & & & & & & & & & \\
\hline & 2 & $\begin{array}{l}2.3 \\
23\end{array}$ & $\begin{array}{l}.63 \\
8\end{array}$ & & & & & & & & \\
\hline
\end{tabular}

\section{Extern}

$\begin{array}{llllllllllll}\text { al } & 1 & 2.1 & .75 & & & & -.573 & 0.745 & & - & \\ \text { barrier } & 1 & 23 & 2 & 35 & -7.599 & .00 & & & - & .42 & 0.813 \\ \mathrm{~s} & & & & 9 & & 0 & & & .721 & 5 & \\ & 2 & 2.6 & .67 & & & & & & & & \\ & 2 & 96 & 8 & & & & & & & & \end{array}$

Note: 1 = Active; 2 = Less active

This study results found that there was a statistically significant difference in internal attributes scores for respondents who active participation in physical activity $(M=2.006$, $\mathrm{SD}=0.619)$ and less active participation in physical activity $(\mathrm{M}=2.323, \mathrm{SD}=0.638) ; \mathrm{t}(359)=-$ $4.786, p<0.05$. Cohen suggested that $d=0.2$ be considered a 'small' effect size, 0.5 represents a 'medium' effect size and 0.8 a 'large' effect size. Based on Cohen's guidelines, the magnitude of the differences in the means (mean difference $=-0.317,95 \% \mathrm{Cl}:-0.447$ to -0.186 ) has medium effect (eta squared $=0.580$ ).

In terms of external barriers, data findings indicate a statistically significant difference in scores for respondents who had actively participated $(M=2.123, S D=0.752)$ and less active participated $(M=2.696, S D=0.678)$ in regular physical activity; $t(359)=-7.599, p<0.05$. The magnitude of the differences in the means (mean difference $=-0.573,95 \% \mathrm{Cl}:-0.721$ to 0.424 ) has slightly large effect (eta squared $=0.792$ ). Therefore, these results reveal that level of attributes certainly influence the participation in physical activity among university students. 


\section{Discussion}

The success of the nation depends on the younger generation who are not only equipped with some degree of knowledge and skills but also need to acquire a substantial level of physical fitness. Thus, in achieving physically and mentally fit individuals, participation in sport or physical activity is of supreme importance. Engagement in physical activity is recognised as an essential factor contributing to positive health benefits. Despite the benefits associated with regular physical activity and its ability to improve health, there is little evidence to suggest that the prevalence of physical inactivity among university students is increasing (Dhurup \& Garnett, 2011). This study discovered the internal and external barriers to physical activity among university students.

Generally, this study revealed that the rate of active participation amongst university student is about 50 per cent and the other half is in the categories of less active and inactive. The result has shown that male students were more actively participate in physical activity than female students. Male respondents seem to be actively involved in their daily exercises and sport in any circumstances and condition. A similar study conducted by Chui (2016) among young Malaysians also found that male respondents were higher percentage cited compared female respondents. Furthermore, students in the upper-level semester (part 5 and 6) were reported more actively in physical activity compared to lower semester students. Typically, students in the early semester spend more time for adjusting and adapting to the new learning tools and environment. At the beginning journey in the university world, students' lives become more competitive and struggle in acclimating to the new environment. Meanwhile, they also need to quick response to the challenging times in their life without a family. In contrast with students in the upper-level semester or final year who have more comfortable and manageable in their life campus. Thus, they can spend their time to leisure and involve in physical activities.

The findings of this study also discovered that both perceived internal and external barriers in physical activity were statistically significant differences in mean scores between both categories of respondents. It was shown that perceived external barriers considered as more important than perceived internal barriers. The external barriers such as lack of resources, support and time were becoming the main obstacles to the students in actively participated in their daily physical activities. Due to Covid-19, all the fitness centres were closed as aligned with government restrictions in Malaysia, and in the time most of the respondents also claimed that they have no exercise equipment at home; therefore, they cannot do the physical activities as usual. The reasons cited by the respondents for not participating in sport or physical activity were consistent with previous related studies which include lack of facilities, times, family, and friends discourages, and social experiences (Wilson, 2006; Aminuddin et al., 2009 \& Thatcher, 2009). Furthermore, other distractions such as lack of facilities, proper gear and equipment were found as the most important barriers among students in engaging in their physical activity (Dhurup \& Garnett, 2011).

Although physical activity plays a vital role in improving and maintaining the health and well-being of every individual, there are distractions and obstructions that faced by them. In these findings, lack of time was indicated the most prominent attribution among inactive students. Most of the respondents claimed that they more spent their daily time on the lesson, social and family responsibilities; consequently, they have no leisure time for physical activity. The result of this study was supported by a survey conducted by Oluyinka and Endozo (2019) that identified lack of time due to busy lesson schedule was the most significant factors for not participating in physical activity among the respondents. Besides, a study among 
Nigerian university students also revealed that lack of time was one of the most crucial external factors to physical activity participation. In contrast, lack of motivation was the most important internal factor that somewhat affects the involvement of the respondents in doing physical activity (Dhurup, 2012). Another study also proved that 'not having enough time' and the pressures of a university schedule were cited to be a significant external constraint for participation in physical activity and exercise (Dhurup \& Garnett, 2011; Manaf, 2013).

\section{Conclusion}

In conclusion, the present study adds to the existing literature on the barriers to participation in physical activity and exercise among university students. The results show that most university students were moderately active in terms of their sport or physical activity participation. Overall, the rate of active participation amongst them is about 50 per cent and the other half is in the categories of less active and inactive. Besides, despite most of the studies on sport and physical activity involvement among youths in Malaysia were found to be the most active as compared with other age groups, yet their level of participation seems not up to the recommended level as suggested by the World Health Organization (2009) and the American College of Sports Medicine (2007). The results of this study indicate that university students have multiple barriers to the sport or physical activity participation. The common obstacles for those who do not participate in sport and physical activity included 'do not have enough time', 'lack of support' and 'lack of facilities'. This study also revealed that there are significant differences in mean score for both internal and external barriers among both categories of students, i.e., active, and inactive. Since the data in this study were collected during a national lockdown of Covid-19, such information is vital for the necessary knowledge to create a formulation of guidelines that aim to help university students to overcome barriers to participation in physical activity and exercise, as well as for the creation of structured strategies to improve adherence to exercise. Furthermore, the primary contribution of sport and physical activity participation is not only the frequency and the awareness of engaging in those activities, but above all, the benefits and satisfaction obtained. Therefore, information from this study will be able to assist all parties such as a parent, government as well as university students itself to encourage them to actively involved in sport and physical activities every day and anywhere. The leisure practitioners (include sport, recreation, and physical activity) also can use the findings of this survey to design, plan, and offer services which contribute not only to increase the rate of participation but also to fulfil leisure satisfaction and psychological well-being of young Malaysians especially university students. Thus, the authority concerns must be aware of this diversity, and at the time a need to design some practical strategies for overcoming common barriers to sport participation. It is important that they can use the findings of this study to create a sporting situation which will motivate and minimize the existing inhibiting factors among the university students to involve in sport or physical activity.

\section{Acknowledgement}

We would like to express our sincere gratitude to Universiti Teknologi MARA, (UiTM) Cawangan Selangor and the Faculty of Business and Management, Universiti Teknologi MARA (UiTM) Kampus Puncak Alam, for their kind support and contributions. 


\section{References}

Allison, K. R., Dwyer, J. J., \& Makin, S. (1999). Self-efficacy and participation in vigorous physical activity by high school students. Health Education \& Behavior, 26(1), 12-24.

Aminuddin, Y., Abdullah, M. N. H., Fauzee, M. S. O., Soh, K. G., Ismail, I. A., Abdullah, A. L., \& Adam, Y. (2009). Kajian penglibatan golongan belia dan masyarakat dalam sukan. Laporan akhir akademi Sukan, Universiti Putra Malaysia.

Bray, S. R. (2007). Self-efficacy for coping with barriers helps students stay physically active during transition to their first year at a university. Research Quarterly for Exercise and Sport, 78(2), 61-70.

Chiu, L. K., Yusof, M. M., Fauzee, M. S. O., Othman, A. T., Aman, M. S., Elumalai, G., \& Ali, H. M. (2016). Examining sport and physical activity participation, motivations and barriers among young Malaysians. Asian Social Science, 12(1), 159.

Daskapan, A., Tuzun, E. H., \& Eker, L. (2006). Perceived barriers to physical activity in university students. Journal of Sports Science and Medicine.

Dhurup, M. (2012). A dimensional analysis of the benefits derived from physical activity participation among university students and variation in terms of gender: Health. African Journal for Physical Health Education, Recreation and Dance, 18(3), 614-627.

Dhurup, M., \& Garnett, A. (2011). Self-reported constraints to physical activity participation among university students. African Journal for Physical Health Education, Recreation and Dance, 17(Supplement 2), 86-103.

Eskiler, E., \& Küçükibis, H. F. (2019). Sources of Social Support in Physical Activity Participation: The Moderating Effect of Gender. International Journal of Psychology and Educational Studies, 6(3), 80-88. https://doi.org/10.17220/ijpes.2019.03.009

Fuchs, R. (2015). Physical Activity and Health. In International Encyclopedia of the Social \& Behavioral Sciences: Second Edition. https://doi.org/10.1016/B978-0-08-0970868.14115-7

Gómez-López, M., Gallegos, A. G., \& Extremera, A. B. (2010). Perceived barriers by university students in the practice of physical activities. Journal of Sports Science and Medicine.

Herazo-Beltrán, Y., Pinillos, Y., Vidarte, J., Crissien, E., Suarez, D., \& García, R. (2017). Predictors of perceived barriers to physical activity in the general adult population: a cross-sectional study. Brazilian Journal of Physical Therapy. https://doi.org/10.1016/j.bjpt.2016.04.003

Institute for Public Health (IPH). (2019). National Health and Morbidity Survey (NHMS) 2019 : Vol. 1: NCDs - Non-Communicable Diseases: Risk Factors and other Health Problems. In Ministry of Health Malaysia.

Kann, L., McManus, T., Harris, W. A., Shanklin, S. L., Flint, K. H., Queen, B., Lowry, R., Chyen, D., Whittle, L., Thornton, J., Lim, C., Bradford, D., Yamakawa, Y., Leon, M., Brener, N., \& Ethier, K. A. (2018). Youth risk behavior surveillance - United States, 2017. MMWR Surveillance Summaries. https://doi.org/10.15585/mmwr.ss670

Korkiakangas, E. E., Alahuhta, M. A., \& Laitinen, J. H. (2009). Barriers to regular exercise among adults at high risk or diagnosed with type 2 diabetes: a systematic review. Health promotion international, 24(4), 416-427.

Leslie, E., Owen, N., Salmon, J., Bauman, A., Sallis, J. F., \& Lo, S. K. (1999). Insufficiently active Australian college students: perceived personal, social, and environmental influences. Preventive medicine, 28(1), 20-27.

Manaf, H. (2013). Barriers to participation in physical activity and exercise among middleaged and elderly individuals. Singapore Med J, 54(10), 581-586. 
Morgan, K. (1971). Sample Size Determination Using Krejcie and Morgan Table. Kenya Projects Organization (KENPRO).

Oluyinka, S., \& Endozo, A. (2019). Factors Affecting Physical Activity Participation Among University Students. Journal of Social Science Research, 14, 3161-3170.

Rogers, L. Q., Carter, S. J., Williams, G., \& Courneya, K. S. (2018). Physical activity. In Handbook of Cancer Survivorship: Second Edition. https://doi.org/10.1007/978-3-319-77432-9_15

Saleem, F., Bashaar, M., \& Hassali, M. A. (2018). Assessment of barriers to physical activities among university students in Malaysia. Pharm Pharmacol Int J, 6(6), 468-473.

Sandu, D., Toth, G., \& Tudor, E. (2018). The nexus of motivation-experience in the migration process of young Romanians. Population, Space and Place. https://doi.org/10.1002/psp.2114

Sullum, J., Clark, M. M., \& King, T. K. (2000). Predictors of exercise relapse in a college population. Journal of the American College Health Association. https://doi.org/10.1080/07448480009595693

Thatcher, J. (2009). Motivation in sport and exercise. In J. Thatcher, R. Thatcher, M. Day, A. Portas, \& S. Hood (Eds.), Sport and exercise science (pp. 67-85). Exeter: Learning Matters.

Trost, S. G., Owen, N., Bauman, A. E., Sallis, J. F., \& Brown, W. (2002). Correlates of adults' participation in physical activity: review and update. / Etude des facteurs sociaux, personnels et culturels entourant la participation a une activite physique pour des adultes. Medicine \& Science in Sports \& Exercise.

Wallace, L. S., Buckworth, J., Kirby, T. E., \& Sherman, W. M. (2000). Characteristics of exercise behavior among college students: application of social cognitive theory to predicting stage of change. Preventive medicine, 31(5), 494-505.

Warburton, D. E. R., Nicol, C. W., \& Bredin, S. S. D. (2006). Health benefits of physical activity: The evidence. In CMAJ. https://doi.org/10.1503/cmaj.051351

Weyerer, S., \& Kupfer, B. (1994). Physical Exercise and Psychological Health. In Sports Medicine: An International Journal of Applied Medicine and Science in Sport and Exercise. https://doi.org/10.2165/00007256-199417020-00003

Wilson, N. C. (2006). Preliminary study of the physical activity participation patterns of Malaysian youth. Kuala Lumpur: Majlis Sukan Negara Malaysia. 